\title{
An Approach to the Quality of Drinking Water as a Matter of Multicriterial Decision
}

\author{
Amelia Bucur \\ Department of Mathematics and Informatics \\ Lucian Blaga University of Sibiu, Romania, \\ amelia.bucur@ulbsibiu.ro \\ Jose L.Lopez-Bonilla \\ ESIME-Zacatenco, National Polytechnic Institute,Anexo Edif. 5, Col. \\ Lindavista CO 07738 Mexico city, Mexico \\ jlopezb@ipn.mx
}

Received: February 23, 2019. Revised: April 3, 2021. Accepted: September 12, 2021. Published: November 15, 2021.

\begin{abstract}
The aim of the present paper is to approach the matter of water quality by resorting to the metod of multicriterial mathematical programming. MicrosoftExcel enables the simulation of a mathematical model. Furthermore, we have also created a file in the $\mathrm{C}++$ software, in view of the simulation process, applicable to numberless properties of water quality. The case study presents the simulation of a multicriterial analysis of water quality in Sibiu county. This particular study shows the means of obtaining more information about water quality, subsequent to the analysis of its characteristics resorting to statistical analysis-specific software, e.g. SPSS 16 software. Given the increase of drinking water worldwide by tens of percentage points in cca two decades, the author(s) consider(s) that an approach to the quality management of drinking water should represent a key priority of society.
\end{abstract}

Keywords: quality of drinking water, multicriterial modeling, simulation

\section{I.INTRODUCTION}

Contemporary society has evinced, at national and international level, a consistent preoccupation for the continuous quality improvement of drinking water (e.g. Cude, C.G., 2001; Gurzau, A.E., Popovici, E., Pintea, A., Popa, O., Pop, C. \& Dumitrascu, I., 2010; Güler, C., Thyne, G.D., McCray, J.E. \& Turner, A.K., 2002; Oprean, L., Poplăcean, M., Georgescu, N., 2004,2005; Sa'nchez, E., Colmenarejo, M.F., Vicente, J., Rubio,A., Garcı'a, M.G., Travieso, L. \& Borja, R., 2007; Singha, K.P., Malika, A., Mohana, D. \& Sinhab, S., 2004). Certain West-European countries are monitoring 45 indicators regarding water quality, whereas the European Economic Commission regulations, approved in 1980, recommend a constant monitoring of 62 characteristics of drinking water.
There is a constant preoccupation in all developed countries for controlling water pollution, since the quality of drinking water contributes significantly to the health of a nation. There are special law, in our country as well, meant to fight against water pollution. On the other hand, in certain countries the current consumption of drinking water per capita is very high, therefore specialists recommend a more rational use of water as well as warning about the danger of water resource depletion and pollution in the future. It si estimated that the demand of drinking water shall increase by tens of percentage points in approximately two decades and thus billions of people might suffer from thirst or live in precarious conditions, therefore the interest in the quality management of drinking water is fully justified and should represent a key priority of societies.

The present paper aims to approach the topic of drinking water as a matter of multicriterial decision, considering that multicriteriral mathematical modeling enables numberless applications to management and decision theory. According to specialized literature (Resteanu, 2006), the decision-making process in the field of drinking water quality represents a set of activities that rely on the awareness of the multitude possibilities to act at any given time, analysis of their consequences in relation to a specific goal, selection and implementation of the axiologically optimal action. In this respect, one may resort to the Multi-Attribute Decision-Making (MADM) able to solve the Optimal Choice Problem (OCP).

Multicriterial programming represents a significant chapter of mathematical optimization, and implicitly of operational research; its significance in decision-problem solving is increasing since the specific methods for this branch of mathematical programming is applicable to a wide array of practical problems, incluing those related to quality management.

Should there be more objective functions, the optimal solution for a function may not be optimal for 
other functions, hence we introduce the notion of solution achieving ,the best compromise" known as non-dominant solution, effective solution, PARETdefined optimal solution, etc. The multicriterial problem or multi-function objective nowadays represents a self-standing chapter of the multiple criteria decision theory.

\section{II.MATHEMATICAL MULTICRITERIAL MODELING OF THE QUALITY OF DRINKING WATER}

In view of taking into account as many decision criteria as possible, we have designed and developed a specific application for the multi-criteria decision situation in the field of classifying various types of drinking water, selected from various sources, according to the quality properties of water. In order to solve the multi-criterial problem, we have started from the decision matrix available in specialized literature in keeping with the model in Table 1:

Table 1. Decision matrix for a multi-criterial problem

\begin{tabular}{|c|c|c|c|c|c|c|c|c|c|c|c|c|c|c|c|}
\hline Situations & & & $S_{\text {] }}$ & & & & & $S_{h}$ & & & & & $\mathrm{~S}_{\mathrm{i}}$ & & \\
\hline $\begin{array}{l}\text { Criterions } \\
\text { of decision }\end{array}$ & $C_{1}$ & - & $C_{i}$ & $\ldots$ & $C_{n}$ & $C_{1}$ & $\ldots$ & $C_{i}$ & $\ldots$ & $C_{n}$ & $C_{1}$ & $\ldots$ & $C_{i}$ & $\ldots$ & $C_{n}$ \\
\hline $\begin{array}{l}\text { Cosfficients } \\
\text { of } \\
\text { ingortanos }\end{array}$ & $k$. & ... & $k_{j}$ & $\ldots$ & $k_{n}$ & $k$. & ... & $k_{j}$ & $\ldots$ & $k_{n}$ & $k$. & a.. & $k_{j}$ & ... & $k_{n}$ \\
\hline$V_{1}$ & a!1!1 & & $a_{1 ; i}$ & $\ldots$ & $\mathrm{a} ! n !$ & a!llh & $\ldots$ & $a_{\mathrm{j} i \mathrm{~h}}$ & $\ldots$ & alnh & a $111 \mathrm{~s}$ & $\ldots$ & $a_{\text {is }}$ & $\ldots$ & a!ns \\
\hline $\mathrm{V}_{2}$ & a 211 & & $a_{2 i 1}$ & $\ldots$ & $a_{2 n !}$ & $a_{2 ! h}$ & $\ldots$ & $a_{2 i h}$ & $\ldots$ & $a_{2 n h}$ & $a_{21: 5}$ & $\ldots$ & $a_{2 j \mathrm{i}}$ & $\ldots$ & $a_{2 n s}$ \\
\hline$m$ & $\ldots$ & $\ldots$ & $\ldots$ & $\ldots$ & $\ldots$ & $\ldots$ & $\ldots$ & $\ldots$ & $\ldots$ & $\ldots$ & $\ldots$ & $\ldots$ & $\ldots$ & $\ldots$ & $\ldots$ \\
\hline$V_{i}$ & $a_{i 11}$ & & $a_{i j}$. & $\ldots$ & $a_{i n 1}$ & ailh & $\ldots$ & $a_{j i h}$ & $\ldots$ & $a_{\text {inh }}$ & $a_{i 1.5}$ & $\ldots$ & $a_{i j i}$ & $\ldots$ & ains \\
\hline$m$ & $\ldots$ & $\ldots$ & $\ldots$ & $\ldots$ & $\ldots$ & $\ldots$ & $\ldots$ & $\ldots$ & $\ldots$ & $\ldots$ & $\ldots$ & $\ldots$ & $\ldots$ & $\ldots$ & $\ldots$ \\
\hline$V_{\mathrm{m}}$ & $a_{m 11}$ & & $a_{m i l}$ & $\ldots$ & $\mathrm{amn}$ & $a_{m l h}$ & $\ldots$ & $a_{\operatorname{mih}}$ & $\ldots$ & $a_{m i n h}$ & $a_{m l i}$ & $\ldots$ & $a_{\operatorname{mit}}$ & $\ldots$ & $a_{m m}$ \\
\hline
\end{tabular}

where: $V_{i}=i$ alternative, for $i=1,2,3 \ldots . . . m$;

$\mathrm{S}_{\mathrm{h}}$ objective situation $\mathrm{h}$, for $\mathrm{h}=1,2,3 \ldots \ldots \mathrm{s}$;

$\mathrm{C}_{\mathrm{j}}-\mathrm{j}$ criterion for $\mathrm{j}=1,2,3 \ldots \ldots \mathrm{n}$;

$k_{j}$ - significance criterion ( $\mathrm{j}$ criterion weight) for $\mathrm{j}=1,2,3 \ldots \mathrm{n}$;

$\mathrm{a}_{\mathrm{ijh}}-\mathrm{i}$ alternative consequence (performance)

for the $\mathrm{j}$ criterion under $\mathrm{h}$ objective circumstances (under the provision of the $\mathrm{h}$ situation).

There may be:

\section{Let us mention potential situations:}

$\mathrm{S}_{1}=$ using relevant materials for performing water quality analysis;

$\mathrm{S}_{2}$ employing qualified staff, experienced for data analysis and interpretation;

$\mathrm{S}_{3}$ failure of raising funds for performing analysis.

The problem of multi-criterial decision shall be solved is the above-mentioned situations $\left(\mathrm{S}_{1}, \mathrm{~S}_{2}, \mathrm{~S}_{3}\right)$ have the following occurrence probabilities: $\mathrm{p}\left(\mathrm{S}_{1}\right)=0,4$, $\mathrm{p}\left(\mathrm{S}_{2}\right)=0,5, \mathrm{p}\left(\mathrm{S}_{3}\right)=0,1$.

2.The criteria related to the types of water are:

$$
\begin{aligned}
& \mathrm{C}_{1}=\mathrm{pH} ; \\
& \mathrm{C}_{2} \text { cost; } \\
& \mathrm{C}_{3} \text { chlorine concentration; } \\
& \mathrm{C}_{4} \text { calcium concentration; } \\
& \mathrm{C}_{5} \text { magnesium concentration. }
\end{aligned}
$$

3. The significance criteria coefficients are: $k_{l}=0,3$, $k_{2}=0,2, k_{3}=0,2, k_{4}=0,15, k_{5}=0,15$.

\section{Types of water may be:}

$\mathrm{V}_{1}=$ Avrig tap water(Sibiu area,Romania);

$\mathrm{V}_{2}$ Sibiu tap water (Calea Dumbravii from Sibu area, Romania);

$\mathrm{V}_{3}$ bottled water DORNA(still water, Romania);

$\mathrm{V}_{4}$ spring water (Sadu area, from Sibiu, Romania);

$\mathrm{V}_{5}$ bottled water QLARIVIA (immaculate water, Romania);

$\mathrm{V}_{6}$ bottled water BORSEC (still water, Romania);

$\mathrm{V}_{7}$ Cisnadie tap water(Sibiu area, Romania).

The $\mathrm{a}_{\mathrm{ijh}}$ elements inside the matrices in table 1 represent a product among the values assigned to the $C_{j}$ criterion on a Likert scale from 1 to 5 , i.e. $\mathrm{N}_{\mathrm{i}}\left(\mathrm{C}_{\mathrm{j}}\right)$ of the $k_{j}$ significance coefficient and the $\mathrm{p}\left(\mathrm{S}_{\mathrm{h}}\right)$ situation occurrence probabilities. This product is calculated by the formula:

$$
\mathrm{a}_{\mathrm{ijh}}=\mathrm{N}_{\mathrm{i}}\left(\mathrm{C}_{\mathrm{j}}\right) k_{j} \mathrm{p}\left(\mathrm{S}_{\mathrm{h}}\right)
$$

where $\mathrm{i}=1,2,3,4,5, \mathrm{j}=1,2,3, \mathrm{~h}=1,2,3$.

This is a subjective estimation of values and relies on the prior experience of those involved in the process of water sample analysis.

Table 2. Levels of $\mathrm{N}_{\mathrm{i}}\left(\mathrm{C}_{\mathrm{j}}\right)$ values assigned to the $\mathrm{C}_{\mathrm{j}}$ criteria on a Likert scale form 1 to 5

\begin{tabular}{|c|c|c|c|c|c|c|c|c|c|c|c|c|c|c|c|c|}
\hline Situations & & & $=0,4$ & & & & & $\left(S_{S}\right)=0$ & & & & & $8_{3}=0,1$ & & & \\
\hline $\begin{array}{l}\text { Crittrions } \\
\text { of decion }\end{array}$ & $c_{1}$ & $C_{2}$ & $C_{3}$ & $C_{4}$ & $C_{s}$ & $C_{1}$ & & $C_{2}$ & $c_{3}$ & $C_{4}$ & Cs & $C_{1}$ & $a_{2}$ & $c_{3}$ & $C_{4}$ & $c_{1}$ \\
\hline $\begin{array}{l}\text { Cosflicists } \\
\text { of } \\
\text { inportans }\end{array}$ & 0,3 & 0,2 & 0,2 & 0,15 & 0,15 & 0 & & 0,2 & 0,2 & 0,15 & 0,15 & 0,3 & 0,2 & 0,2 & 15 & 0,15 \\
\hline$V_{1}$ & 0,48 & 0,40 & 0,24 & 0,18 & 0,24 & 0 & & 0,10 & 0,30 & 0,08 & 0,23 & 0,12 & 0,10 & 0,06 & 0,05 & 0,10 \\
\hline$V_{2}$ & 0,36 & 0,24 & 0,40 & 0,24 & 0,30 & 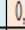 & & 0,30 & 0,50 & 0,15 & 0,30 & 0,09 & 0,06 & 0,10 & 0,10 & 0,05 \\
\hline$V_{3}$ & 0,60 & 0,32 & 0,24 & 0,30 & 0,06 & & & 0,40 & 0,30 & 0,23 & 0,38 & 0,09 & 0,08 & 0,06 & 0,20 & 0,15 \\
\hline$V_{4}$ & 0,48 & 0,32 & 0,32 & 0,06 & 0,03 & 0 & & 0,30 & 0,40 & 0,30 & 0,15 & 0,12 & 0,04 & 0,08 & 0,15 & 0,20 \\
\hline$V_{5}$ & 0,60 & 0,24 & 0,40 & 0 & 0,06 & & & 0,30 & 0,50 & 0,38 & 0,08 & 0,15 & 0,06 & 0,10 & 0,20 & 0,25 \\
\hline$\overline{V_{6}}$ & 0,30 & 0,24 & 0,32 & 0,18 & 0,18 & 0 & & 0,20 & 0,40 & 0,30 & 0,15 & 0,12 & 0,04 & 0,02 & 0,25 & 0,20 \\
\hline$V_{1}$ & 0,60 & 0,24 & 0,08 & 0,06 & 0.2 & & & 0,10 & & 0,23 & 0,23 & 0,09 & 0,02 & 0,04 & 0,15 & 0,15 \\
\hline
\end{tabular}

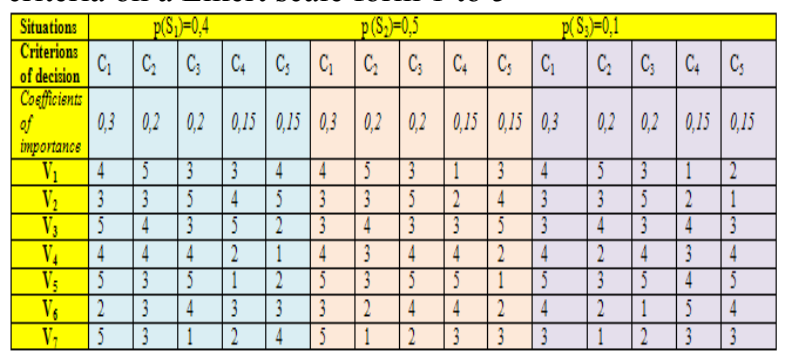

According to formula (1), all $\mathrm{a}_{\mathrm{ijh}}$ elements are automatically calculated and displayed:

Table 2. The decision matrix for the proposed multicriterial problem

Based on the decision matrices in Tables 1 and 2, several decision methods and criteria may be applied, such as: the „mathematical hope" method (whenever the $\mathrm{S}_{\mathrm{i}}$ occurrence probabilities are known) which we have chosen to use in the present paper.

The application of the aforementioned method requires that all criteria should be assessed by the same measurement unit on the Likert scale. Therefore:

- first, let us proceed to transforming all consequences in significances, according to the mathematical model:

$$
\mathrm{U}_{\mathrm{ijh}}=\left(\mathrm{a}_{\mathrm{ijh}}-\mathrm{a}_{\mathrm{jh}}^{\mathrm{o}}\right) /\left(\mathrm{a}_{\mathrm{ijh}}^{\prime}-\mathrm{a}_{\mathrm{jh}}^{\mathrm{o}}\right)
$$


where: $\mathrm{U}_{\mathrm{ijh}}$ - relevance of the $\mathrm{i}$ version consequences, for the $\mathrm{j}$ criterion given the $\mathrm{h}\left(\mathrm{a}_{\mathrm{ijh}}\right)$ objective circumstances (situation);

$\mathrm{a}_{\mathrm{j}}^{\prime}$ - the most favourable consequence for the $\mathrm{j}$ criterion given the h objective circumstances;

$a_{j}^{o}$ - the least favourable consequence for the same $j$ criterion given the $\mathrm{h}$ objective circumstances:

Table 3. Relevance matrices for the proposed multicriterial problem

\begin{tabular}{|c|c|c|c|c|c|c|c|c|c|c|c|c|c|c|c|}
\hline Situations & \multicolumn{6}{|c|}{$p\left(S_{1}\right)=0,4$} & \multicolumn{5}{|c|}{$p\left(S_{2}\right)=0,5$} & \multicolumn{4}{|c|}{$p\left(S_{3}\right)=0,1$} \\
\hline $\begin{array}{l}\text { Criterions } \\
\text { ffdecizinon }\end{array}$ & $C_{1}$ & $c_{2}$ & $C_{3}$ & $C_{4}$ & $c_{3}$ & $\mathrm{C}_{1}$ & $C_{2}$ & $C_{3}$ & $C_{4}$ & $c_{s}$ & $\mathrm{C}_{1}$ & $c_{2}$ & $C_{3}$ & $\mathrm{C}_{4}$ & $C_{s}$ \\
\hline $\begin{array}{l}\text { Corfection } \\
\text { of }\end{array}$ & 0,3 & 0,2 & 0,2 & 0,15 & 0,15 & 0,3 & 0,2 & 0,2 & 0,15 & 0,15 & 0,3 & 0,2 & 0,2 & 0,15 & 0,15 \\
\hline$\frac{\text { poratance }}{V_{1}}$ & 0,50 & \begin{tabular}{|l}
1,00 \\
\end{tabular} & 0,00 & 0.56 & 0,78 & 0,50 & 0,00 & 0.00 & 0,00 & \begin{tabular}{|l}
0.50 \\
\end{tabular} & 0,50 & 1,00 & 0,00 & 0,00 & 0.25 \\
\hline$V_{2}$ & \begin{tabular}{|l|l} 
\\
0,00
\end{tabular} & \begin{tabular}{|l|}
0,00 \\
\end{tabular} & 1,00 &, 8 & \begin{tabular}{|l|l|}
, 1.00 \\
\end{tabular} & 0,00 & \begin{tabular}{|l|}
$, 0,67$ \\
\end{tabular} & .00 & 0,25 & \begin{tabular}{|l|}
0,75 \\
\end{tabular} & +1 & 33 & & \begin{tabular}{|l|l}
0,33 \\
\end{tabular} & 00 \\
\hline$V_{3}$ & \begin{tabular}{|l|l|}
1,00 \\
\end{tabular} & 0,50 & 0,00 & .00 & 0,11 & 0,00 & .00 & $\begin{array}{l}0,00 \\
\end{array}$ & 0 & 1,00 & 0, & 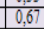 & 0, & 1,00 & 0,50 \\
\hline$V_{4}$ & 0,50 & 0,50 & 0,50 & 11 & 0,00 & 0,50 & 0,67 & 0,50 & 0,75 & 0.25 & 0,50 & 0,00 & 0,50 & 0,67 & 0,75 \\
\hline$V_{5}$ & \begin{tabular}{|l|l|}
1,00 \\
\end{tabular} & \begin{tabular}{|l|l}
0,00 \\
\end{tabular} & 1,00 & 0,00 & 0,11 & \begin{tabular}{|l}
, 00 \\
1,00
\end{tabular} & \begin{tabular}{|l|}
$, 0,67$ \\
\end{tabular} & 00 & 00 & \begin{tabular}{|l|l|}
0,00 \\
\end{tabular} & \begin{tabular}{|l|l|} 
\\
1,00
\end{tabular} & \begin{tabular}{|l|l|}
0,33 \\
\end{tabular} & \begin{tabular}{|l|l|}
1,00 \\
\end{tabular} & \begin{tabular}{|l|l|}
1,00 \\
\end{tabular} & \begin{tabular}{|l|l|}
$, 1,00$ \\
\end{tabular} \\
\hline$V_{6}$ & 0,00 & 0,00 & 0,50 & 0,56 & 0,56 & 0,00 & 0,00 & 0,50 & 0,67 & 0,25 & 0,50 & 0,00 & 0,00 & 1,00 & 0,75 \\
\hline $\mathrm{V}$ & 0,00 & 1.00 & 0,00 & 0.00 & 0.00 & 0.50 & 1.00 & 0.00 & 0,00 & 0.00 & 0.00 & 0.75 & 1,00 & 1,00 & 1.00 \\
\hline
\end{tabular}

- for each i decision alternative and for each status of the $h$ objective circumstances, we have calculated the synthetic relevance (multiplying by the relevance coefficient for each criterion):

$$
\mathrm{u}_{\mathrm{Sih}}=\sum \mathrm{k}_{\mathrm{j}} \mathrm{u}_{\mathrm{ijk}}
$$

Table 4. The synthetic relevance matrix for the proposed multicriterial problem

\begin{tabular}{|l|l|l|l|}
\hline $\mathbf{V}_{\mathbf{1}}$ & 0,55 & 0,23 & 0,39 \\
\hline $\mathbf{V}_{\mathbf{2}}$ & 1,21 & 0,38 & 0,33 \\
\hline $\mathbf{V}_{\mathbf{3}}$ & 0,89 & 1,54 & 0,56 \\
\hline $\mathbf{V}_{\mathbf{4}}$ & 0,86 & 1,29 & 1,04 \\
\hline $\mathbf{V}_{\mathbf{5}}$ & 1,00 & 2,19 & 2,42 \\
\hline $\mathbf{V}_{\mathbf{6}}$ & 0,56 & 1,17 & 2,25 \\
\hline $\mathbf{V}_{\mathbf{7}}$ & 0,00 & 0,00 & 1,75 \\
\hline
\end{tabular}

- based on the synthetic relevance, we ahve drawn up a new matrix including the decision variable on the rows and the potential objective situations on the columns. Thus changed, the problem may be aproached like any other unicriterial decision problem. Taking into account the occurrence probability for the objective circumstances $\left(\mathrm{S}_{\mathrm{i}}\right.$ situations), one may choose the decision option with the highest ,mathematical hope":

$$
\mathrm{V}_{\mathrm{opt}}=\sum \mathrm{u}_{\mathrm{Sih}} \cdot \mathrm{p}_{\mathrm{h}}
$$

where: $p_{h}=p\left(S_{h}\right)$ represents the occurrence possibility for the $h$ objective situation:

Table 5. Levels assigned to the variables (types of water) for the proposed multicriterial problem

\begin{tabular}{|l|l|l|l|l|}
\hline $\mathbf{V}_{\mathbf{1}}$ & 0,55 & 0,23 & 0,39 & 0,29 \\
\hline $\mathbf{V}_{\mathbf{2}}$ & 1,21 & 0,38 & 0,33 & 0,50 \\
\hline $\mathbf{V}_{\mathbf{3}}$ & 0,89 & 1,54 & 0,56 & 0,69 \\
\hline $\mathbf{V}_{\mathbf{4}}$ & 0,86 & 1,29 & 1,04 & 0,73 \\
\hline $\mathbf{V}_{\mathbf{5}}$ & 1,00 & 2,19 & 2,42 & 1,22 \\
\hline $\mathbf{V}_{\mathbf{6}}$ & 0,56 & 1,17 & 2,25 & 0,85 \\
\hline $\mathbf{V}_{\mathbf{7}}$ & 0,00 & 0,00 & 1,75 & 0,35 \\
\hline
\end{tabular}

To conclude, one may notice in the final column the following hierarchy of types of water (alternatives):
1) $\mathbf{V}_{\mathbf{5}}$ bottled water - QLARIVIA (immaculate water) = optimum version;

2) $\mathrm{V}_{6}$ drinking water - BORSEC (still water);

3) $\mathrm{V}_{4}$ spring water (Sadu area, Sibiu county - Romania);

4) $\mathrm{V}_{3}$ bottled water - DORNA (still water);

5) $\mathrm{V}_{2}$ tap water from Sibiu, Sibiu county - Romania (area - Calea Dumbrăvii street);

6) $\mathrm{V}_{7}$ tap water from Cisnadie, Sibiu county Romania;

7) $V_{1}$ tap water from Avrig, Sibiu county - Romania.

\section{III.SIMULATING THE MULTICRITERIAL DECISION PROBLEM IN THE HIERARCHY OF TYPES OF WATER, BY MEANS OF MICROSOFT EXCEL}

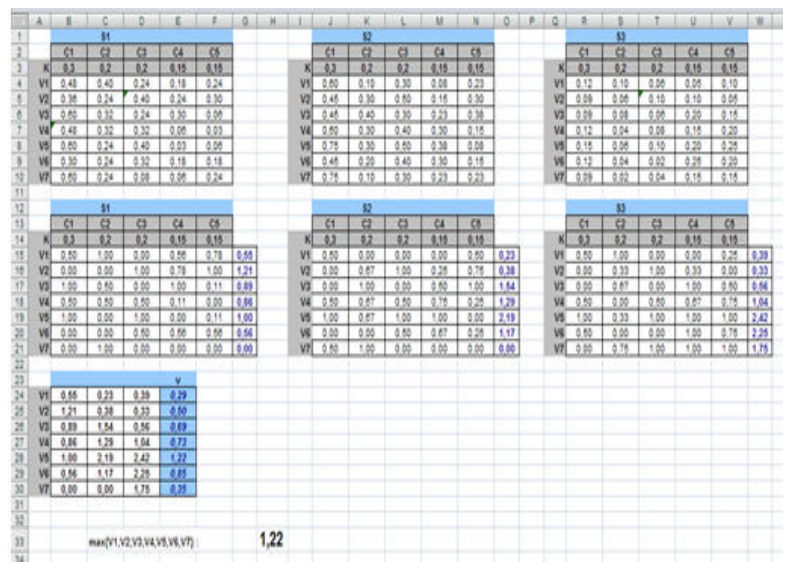

Figure 1. Application in Microsoft Excel

The result is that the $\mathrm{V}_{5}$ version is optimum, thus the QLARIVIA bottled water is the highest quality drinking water, considering that the managerial expertise of specialists in water analysis played an important part in the selection of $\mathrm{a}_{\mathrm{ijh}}$ initial elements:
1) V5
2) $\mathrm{V} 6$
3) V4
4) V3
5) $\mathrm{V} 2$
4) $\mathrm{V7}$
5) $\mathrm{V} 1$

Should the value levels assigned to the $\mathrm{V}_{\mathrm{i}} \mathrm{i}=$ $1, . ., 5$ alternatives on a Likert scale form 1 to 5 , in relation to the $\mathrm{C}_{\mathrm{j}}$ criterion, i.e. $\mathrm{Ni}\left(\mathrm{C}_{\mathrm{j}}\right)$, the $k_{j}$ relevance coefficients and the occurrence probabilities of the $\mathrm{p}\left(\mathrm{S}_{\mathrm{h}}\right)$ situation, then the optimum alternative selected by means of the multicriterial decision would be different. Therefore, its identification depends on estimates and the managerial expertise in interpreting the problem data.

\section{SIMULATING THE MULTICRITERIAL DECISION PROBLEM IN THE HIERARCHY OF TYPES OF WATER, BY MEANS OF THE C++ SOFTWARE}

In this respect, we have designed by means of the $\mathrm{C}++$ language the following software:

\#include $<$ iostream.h $>$

\#include $<$ conio.h $>$

void main() 
\{float

a1 [10][10],a2 [10] [10],a3[10][10],U1[10] [10],U2[10

][10],U3[10][10],

$p[10][10], B[10], N[10][10], S 1, S 2, S 3, k[10]$, min,max;

int $i, j, n, m, t$;

cout $<<$ "Introduceti $n="$ "; in $>>n ; / / n r$ de $v$

cout $<<$ "Introduceti $m="$; cin $>>m ; / / n r$ de c

for $(j=1 ; j<=m ; j++)$

$\{$ cout $<<$ "Introduceti $k["<<j<<"]="$; cin $>>k[j] ;\}$

//Pentru prima matrice introducem datele

cout $<<"$ Dati probabilitatea situatiei $S 1="$; $\operatorname{cin}>>S 1$,

for $(j=1 ; j<=m ; j++)$

for $(i=1 ; i<=n ; i++)$

$\{$ cout $<<$ Introduceti

$N["<<i<<"]["<<j<<"]=$ "; cin $>>N[i][j] ;\}$

for $(i=1 ; i<=n ; i++)$

for $(j=1 ; j<=m ; j++)$

al $[i][j]=N[i][j] * k[j] * S 1$;

for $(i=1 ; i<=n ; i++)$

for $(j=1, j<=m ; j++)$

cout $<<$ "al ["<<i<<"]["<<j<<"]="<<a1[i][j] $<<$ endl

//Pentru matricea a 2-a introducem datele

cout $<<$ "Dati probabilitatea situatiei $S 2=$ "; cin $>>S 2$;

for $(j=1, j<=m ; j++)$

for $(i=1 ; i<=n ; i++)$

$\{$ cout $<<$ Introduceti

$N["<<i<<"]["<<j<<"]=" ; \operatorname{cin}>>N[i][j] ;\}$

for $(i=1 ; i<=n ; i++)$

$\operatorname{for}(j=1 ; j<=m ; j++)$

$a 2[i][j]=N[i][j] * k[j] * S 2$;

for $(i=1 ; i<=n ; i++)$

for $(j=1, j<=m ; j++)$

cout $<<" a 2["<<i<<"]["<<j<<"]="<<a 2[i][j]<<$ endl

//Pentru matricea a 3-a introducem datele

cout $<<$ "Dati probabilitatea situatiei $S 3="$ "; in $>>S 3$;

for $(j=1 ; j<=m ; j++)$

for $(i=1 ; i<=n ; i++)$

$\{$ cout $<<$ Introduceti

$N["<<i<<"]["<<j<<"]=" ; \operatorname{cin}>>N[i][j] ;\}$

for $(i=1 ; i<=n ; i++)$

for $(j=1 ; j<=m ; j++)$

$a 3[i][j]=N[i][j] * k[j] * S 3$;

for $(i=1 ; i<=n ; i++)$

for $(j=1 ; j<=m ; j++)$

cout $<<" a 3["<<i<<"]["<<j<<"]="<<a 3[i][j]<<$ endl

//Trecem la matricea U1

for $(j=1 ; j<=m ; j++)$

$\{\min =10000 ; \max =0$;

for $(i=1 ; i<=n ; i++)$

$\{$ if $(a 1[i][j]<\min ) \min =a 1[i][j]$;

if $(a 1[i][j]>\max ) \max =a 1[i][j] ;\}$

$t=1$;

while $(t<=n)$

$\{U 1[t][j]=(a 1[t][j]-\min ) /(\max -\min )$;

\}

$t++;\}$

$/ *$

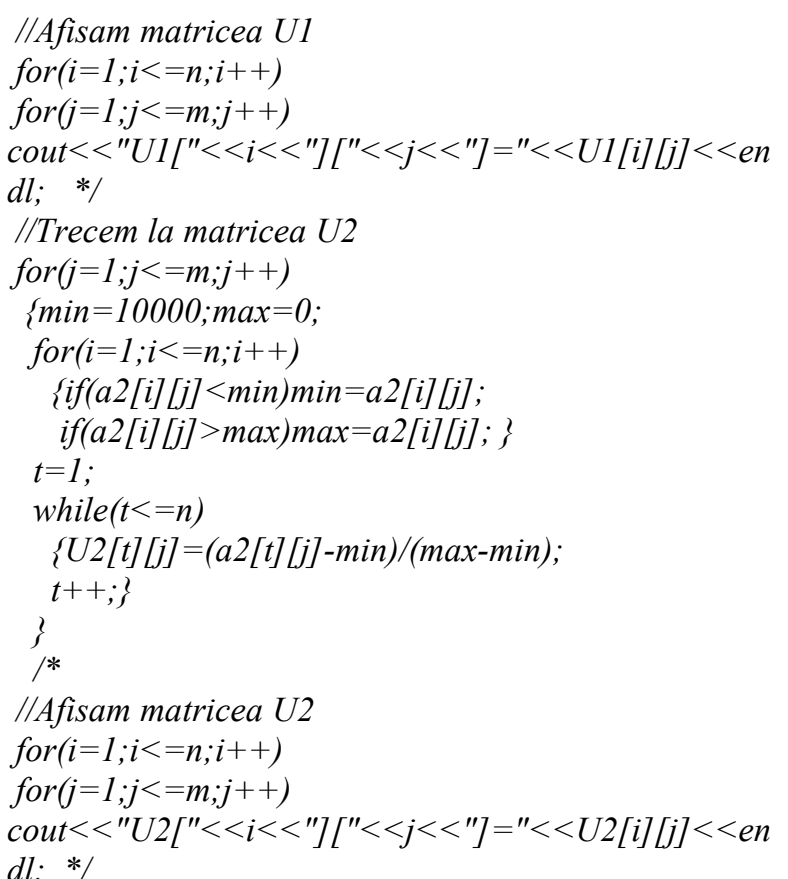

//Trecem la matricea U3

for $(j=1 ; j<=m ; j++)$

$\{\min =10000 ; \max =0$;

for $(i=1 ; i<=n ; i++)$

$\{$ if $(a 3[i][j]<\min ) \min =a 3[i][j]$;

if $(a 3[i][j]>\max ) \max =a 3[i][j] ;$;

$t=1$;

while $(t<=n)$

$\{U 3[t][j]=(a 3[t][j]-\min ) /(\max -\min )$;

$$
t++;\}
$$

\}

//Afisam matricea U3

for $(i=1 ; i<=n ; i++)$

for $(j=1 ; j<=m ; j++)$

cout $<<" U 3["<<i<<"]["<<j<<"]="<<U 3[i][j]<<$ en $d l ; * /$

for $(i=1 ; i<=n ; i++)$

$\{f \operatorname{for}(j=1, j<=m ; j++)$

$p[i][1]=U 1[i][j] * k[j]+p[i][1] ;\}$

${ }^{*}$ for $(i=1 ; i<=n ; i++)$

cout $<<" p["<<i<<"][1]="<<p[i][1]<<$ endl; */

for $(i=1 ; i<=n ; i++)$

$\{$ for $(j=1 ; j<=m ; j++)$

$p[i][2]=p[i][2]+U 2[i][j] * k[j] ;\}$

${ }^{*}$ for $(i=1 ; i<=n ; i++)$

cout $<<" p["<<i<<"][2]="<<p[i][2]<<$ endl; */

for $(i=1 ; i<=n ; i++)$

$\{$ for $(j=1 ; j<=m ; j++)$

$p[i][3]=p[i][3]+U 3[i][j] * k[j] ;\}$

$/ *$ for $(i=1 ; i<=n ; i++)$

cout $<<" p["<<i<<"][3]="<<p[i][3]<<$ endl; */

for $(i=1 ; i<=n ; i++)$

$B[i]=p[i][1] * S 1+p[i][2] * S 2+p[i][3] * S 3$;

for $(i=1 ; i<=n ; i++)$

cout $<<" B["<<i<<"]="<<B[i]<<$ endl;

$\max =0$;

for $(i=1 ; i<=n ; i++)$ 


$$
\begin{aligned}
& \text { if }(B[i]>\max ) \max =B[i] ; \\
& \text { cout }<<" \text { Maximul este }="<<\max ; \\
& \text { getch() }
\end{aligned}
$$

Similar to the Excel simulation process, should one change the levels of values assigned to the $V_{i} i=1, . ., n$ alternatives on a Likert scale form 1 to 5 , in relation to the in relation to the $\mathrm{C}_{\mathrm{j}}$ criterion, i.e. $\mathrm{Ni}\left(\mathrm{C}_{\mathrm{j}}\right)$, the $k_{j}$ relevance coefficients and the occurrence probabilities of the $\mathrm{p}\left(\mathrm{S}_{\mathrm{h}}\right)$ situation, then the optimum alternative selected by means of the multicriterial decision would be different. Therefore, its identification depends on estimates and the managerial expertise in interpreting the problem data.

\section{V.QUALITY OF DRINKING WATER IN SIBIU COUNTY}

A. According to the analysis results, for the quality of the drinking water, available on the website of the S.C. Apă Canal S.A. Sibiu-Romania, here is the total amount of calcium and magnesium, $\mathrm{pH}$, turbidity, nitrite concentration, colour, for the water provided by the Chlorination Stations in Sibiu county, throughout

\begin{tabular}{|c|c|c|c|c|c|c|c|}
\hline $\begin{array}{l}\text { Types of } \\
\text { drinking } \\
\text { water }\end{array}$ & \begin{tabular}{|l|} 
Calcium and \\
magnesium \\
concentration \\
$\left(\mathrm{DH}^{\circ}\right)$
\end{tabular} & $\mathrm{pH}$ (units) & \begin{tabular}{|l} 
Turbidity \\
(NTU)
\end{tabular} & \begin{tabular}{|l|} 
Nitrites \\
$(\mathrm{mg} / \mathrm{l})$
\end{tabular} & $\begin{array}{l}\text { Residual } \\
\text { chlorine } \\
(\mathrm{mg} / \mathrm{l})\end{array}$ & \begin{tabular}{|l|} 
Colour \\
$\left(\mathrm{m}^{-1}\right)$
\end{tabular} & \begin{tabular}{|l|l|l|} 
Place \\
\end{tabular} \\
\hline$V_{l}$ & 0,88 & 6,58 & 2,16 & 0,0020 & 0,41 & 0,41 & $\begin{array}{l}\text { Chlorinated water provided to } \\
\text { the consumerby Cissádie Witro } \\
\text { Treatment Station }\end{array}$ \\
\hline$V_{2}$ & 1,39 & 6,59 & 1,32 & 0,0010 & 0,21 & 0,21 & $\begin{array}{l}\text { Chlorinated water provided to } \\
\text { tha consumer by Lunca Stezil } \\
\text { Water Treatment Station }\end{array}$ \\
\hline$V_{3}$ & 0,93 & 6,77 & 1,16 & 0,0011 & 0,31 & 0,21 & $\begin{array}{l}\text { Chlorinated water provided to } \\
\text { the consumer by Dumbrava } \\
\text { Water Treatment Station }\end{array}$ \\
\hline $\mathrm{V}_{4}$ & 2,41 & 7,33 & 0,45 & 0,0012 & 0,32 & 0,31 & $\begin{array}{l}\text { Chlorinated water provided to } \\
\text { tha consumer by Avrig Watter } \\
\text { Treatment Station }\end{array}$ \\
\hline $\begin{array}{l}\text { Valori } \\
\text { admise }\end{array}$ & 5 & $6,5-9,5$ & 5 & 0,5 & 0,5 & 0,5 & \\
\hline $\begin{array}{c}\text { Standard for } \\
\text { methods }\end{array}$ & $\begin{array}{c}\text { SRISO } \\
6059 / 2008\end{array}$ & $\begin{array}{c}\text { SRISO } \\
105232009\end{array}$ & $\begin{array}{l}\text { SRENISO } \\
70272001\end{array}$ & $\begin{array}{l}\text { SRISO } \\
71500 \\
12001 \\
\end{array}$ & $\begin{array}{c}\text { SIAS } \\
63641.978\end{array}$ & \begin{tabular}{|c|} 
SREV \\
IIO \\
78872002 \\
\end{tabular} & \\
\hline
\end{tabular}
the year 2010:

Table 6. Types of drinking water in Sibiu county

A comparative graphic analysis performed in fig. 2 shows that the drinking water provided by the Avrig Water Treatment Station has the highest calcium and magnesium concentration, therefore it is preferred by those people lacking these minerals, and highly recommended compared to the ones included in table 6 for those suffering from hepatobiliar diseases, thyroid insufficiency, neurosis, hyperacid gastritis, peptic ulcer, rickets, osteomalacia, osteoporosis, muscle cramps, palpitations:

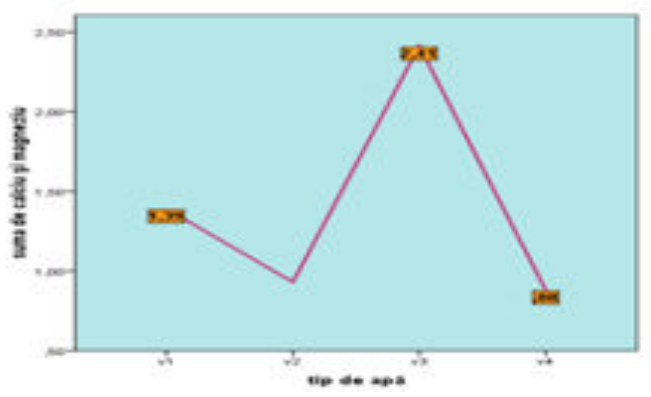

Figure 2. Calcium and magnesium concentration

The calcium and magnesium deficit as well as the low value sof drinking water hardness represent risk factors in cases of morbidity entailed by cardiovascular diseases.

Likewise, the comparative graphic analysis in fig.3 shows that the drinking water provided by the Avrig Water Treatment Station has the highest level of $\mathrm{pH}$, and therefore the most alkaline of all types of water included in table 6 and thus preferred by those consumers who wish to maintain a low level of acidity in their body, since a high acidity may also cause various types of cancer:

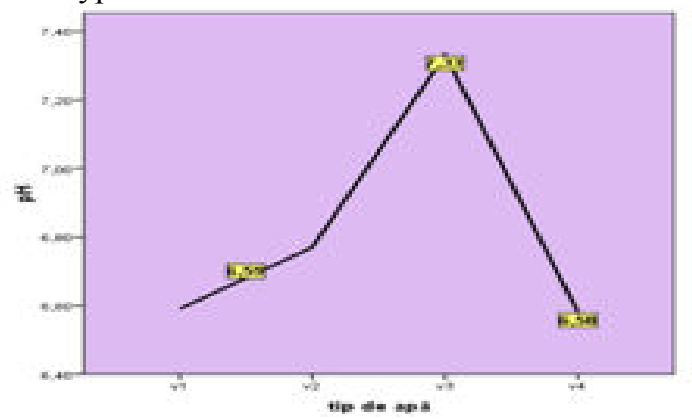

Figure 3. $\mathrm{pH}$ values

Chlorinated water provided to the consumer by Cisnadie Water Treatment Station has the highest level of turbidity of all types of drinking water included in table 6 , therefore the highest concentration of fine particles that may not be easily noticed, which however may diffuse and reflect light when they are in suspension; thus this type of drinking water has a poorer quality than other types of water in the table:

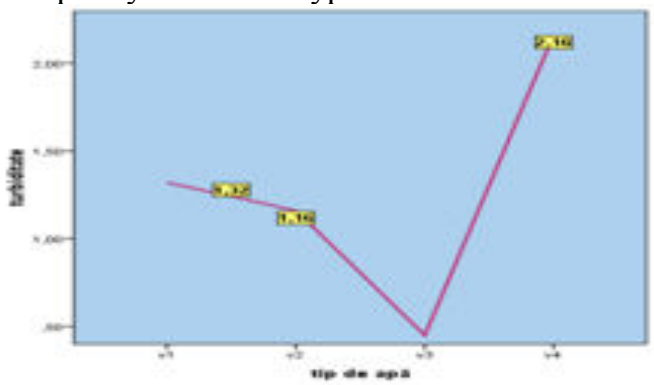

Figure 4. Turbidity of drinking water samples

Chlorinated water from provided ot the consumer by Cisnadie Water Treatment Station has the highest level of nitrites of all types of drinking water included in table 6, therefore it also has the highest toxicity compared to the other ones. Consequently, this reinforces the idea that this type of drinking water is poorer that other types of water in the table: 


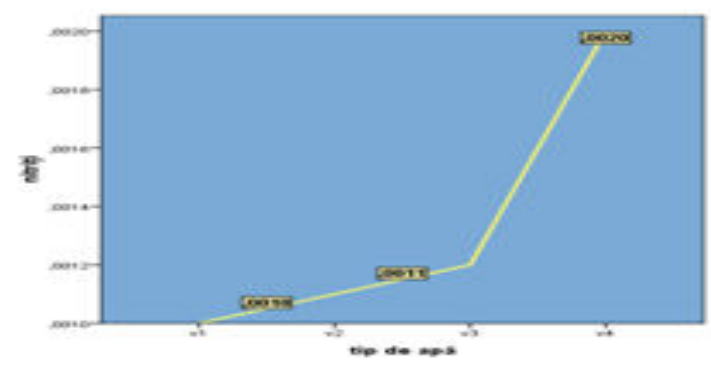

Figure 5. Nitrites concentration

According to specialized studies, high concentrations of chlorine entail organoleptic changes. Any deviation of organoleptic indicators from health norms has serious implications of consumers' psyche, whereas water consumption free of any satisfaction will not quench thirst.

Of all types of drinking water included in table 6, the one provided by Cisnadie Water Treatment Station has the highest level of residual chlorine, which makes it poor in quality, as shown in fig. 6 and 7.

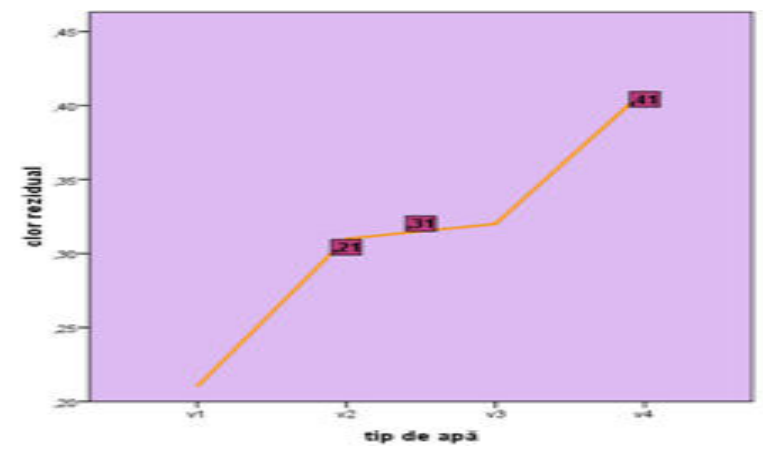

Figure 6. Residual chlorine concentration

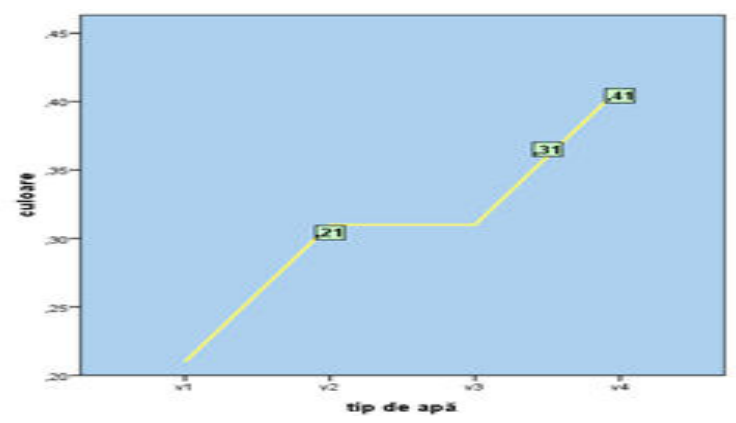

Figure 7. Drinking water sample colour

An analysis the correlation among various quality indicators of drinking water will provide details about the quality of drinking water. Thus, according to table 7 , the correlation coefficient between the indicators „,calcium and magnesium concentration” and „residual chlorine" is -0.235 which indicates a negative correlation, of low intensity, among the two indicators. The increase of one indicators entails a diminishing of the other one.
Table 7. Correlation coefficient between the indicators „calcium and magnesium concentration” and „residual chlorine"

\begin{tabular}{|l|l|r|r|}
\hline & & $\begin{array}{c}\text { Correlations } \\
\text { calcium and } \\
\text { magnesium } \\
\text { concentration }\end{array}$ & residual chlorine \\
\hline calcium and magnesium \\
concentration & Pearson Correlation & 1,000 & $-2,235$ \\
\hline residual chlorine & Sig. (2-tailed) & &, 765 \\
& Pearson Correlation & -235 & 1,000 \\
\hline & Sig. (2-tailed) & 765 & 4 \\
\hline & $N$ & 4,000 & 4,000 \\
\hline
\end{tabular}

According to table 8 , the correlation coefficient between „residual chlorine" and „nitrites" concentration is 0.880 which shows a positive correlation, of high intensity, between the two indicators. The increase of one indicators entails, to a great extent, an increase of the other one.

Table 8. Correlation coefficient between „residual chlorine" and ,nitrites" indicators

\begin{tabular}{|c|c|c|c|}
\hline \multicolumn{4}{|c|}{ Correlations } \\
\hline & & residual chlorine & nitrites \\
\hline \multirow{3}{*}{$\begin{array}{l}\text { residual } \\
\text { chlorine }\end{array}$} & Pearson Correlation & 1,000 &, 880 \\
\hline & Sig. (2-tailed) & &, 120 \\
\hline & $\mathrm{N}$ & 4,000 & 4 \\
\hline \multirow[t]{3}{*}{ nitrites } & Pearson Correlation & 880 & 1,000 \\
\hline & Sig. (2-tailed) & .120 & \\
\hline & $\mathrm{N}$ & 4 & 4,000 \\
\hline
\end{tabular}

According to table 9, the correlation coefficient between „,colour" and „turbidity" indicators is 0.488 which shows a positive correlation, of moderate intensity, between the two indicators. The increase of one indicators entails a moderate impact on the increase of the other one.

Table 9. Correlation coefficient between „colour” and „turbidity” coefficients

\begin{tabular}{|c|c|c|c|}
\hline \multicolumn{4}{|c|}{ Correlations } \\
\hline & & colour & turbidity \\
\hline \multirow[t]{3}{*}{ colour } & Pearson Correlation & 1,000 &, 488 \\
\hline & Sig. (2-tailed) & &, 512 \\
\hline & $\mathrm{N}$ & 4,000 & 4 \\
\hline \multirow[t]{3}{*}{ turbidity } & Pearson Correlation & .488 & 1,000 \\
\hline & Sig. (2-tailed) & 512 & \\
\hline & $\mathrm{N}$ & 4 & 4,000 \\
\hline
\end{tabular}


B. Let us further proceed to approach the quality of drinking water in table 6 , by means of the multicriterial optimization method. A multicriterial analysis enables us to have a unified perspective of all types of drinking water in Sibiu county, instead of a fragmented one, distinct for the quality of each type of drinkig water.

1. We have selected the following criteria for the types of drinking water:

$$
\begin{aligned}
\mathrm{C}_{1}= & \text { calcium and magnesium } \\
& \text { concentration }\left(\mathrm{DH}^{0}\right) ; \\
\mathrm{C}_{2}= & \text { pH( } \text { units }) ; \\
\mathrm{C}_{3}= & \text { turbidity }(\mathrm{NTU}) ; \\
\mathrm{C}_{4}= & \text { nitrites }(\mathrm{mg} / \mathrm{l}) ; \\
\mathrm{C}_{5}= & \text { residual chlorine }(\mathrm{mg} / \mathrm{l}) ; \\
\mathrm{C}_{6}= & \text { colour }\left(\mathrm{m}^{-1}\right) .
\end{aligned}
$$

2.We assume that the criteria relevance coefficients are: $k_{1}=0,1, k_{2}=0,3, k_{3}=0,2, k_{4}=0,2, k_{5}=0,2, k_{6}=0,1$.

3.The types of drinking water subject to quality multicriterial analysis are:

$\mathrm{V}_{1}=$ chlorinated water provided to the consumer by Cisnadie Water Treatment Station;

$\mathrm{V}_{2}$ chlorinated water provided to the consumer by Lunca Stezii Water Treatment Station;

$\mathrm{V}_{3}$ chlorinated water provided to the consumer by Dumbrava Water Treatment Station;

$\mathrm{V}_{4}$ chlorinated water provided to the consumer by Avrig Water Treatment Station.

The $\mathrm{a}_{\mathrm{ij}}$ inside the matrices in table 1 represent here a product of the values assigned to the $C_{j}$ criterion on a Likert scale from 1 to 5 , i.e. $\mathrm{N}_{\mathrm{i}}\left(\mathrm{C}_{\mathrm{j}}\right)$ and the $k_{j}$ relevance coefficients. This product is calculated by the formula:

$$
\mathrm{a}_{\mathrm{ij}}=\mathrm{N}_{\mathrm{i}}\left(\mathrm{C}_{\mathrm{j}}\right) k_{j}
$$

where $i=1,2,3,4,5, j=1,2,3$.

This is a subjective assessment of values and it is determined by the expertise of the specialists in charge of drinking water quality:

Table 10. Levels of $\mathrm{N}_{\mathrm{i}}\left(\mathrm{C}_{\mathrm{j}}\right)$ values assigned to the $\mathrm{C}_{\mathrm{j}}$ criteria on a Likert scale from 1 to 5

\begin{tabular}{|c|l|l|l|l|l|l|}
\hline $\begin{array}{l}\text { Criterions of } \\
\text { decision }\end{array}$ & $\mathrm{C}_{1}$ & $\mathrm{C}_{2}$ & $\mathrm{C}_{3}$ & $\mathrm{C}_{4}$ & $\mathrm{C}_{5}$ & $\mathrm{C}_{6}$ \\
\hline $\begin{array}{l}\text { Cosfficients of } \\
\text { importance }\end{array}$ & 0,1 & 0,3 & 0,2 & 0,2 & 0,2 & 0,1 \\
\hline $\mathrm{V}_{1}$ & 5 & 5 & 4 & 2 & 4 & 3 \\
\hline $\mathrm{V}_{2}$ & 5 & 1 & 3 & 1 & 2 & 5 \\
\hline $\mathrm{V}_{3}$ & 3 & 5 & 4 & 3 & 3 & 4 \\
\hline $\mathrm{V}_{4}$ & 1 & 5 & 1 & 5 & 2 & 1 \\
\hline
\end{tabular}

The $a_{i j}$ elements are automatically calculated and displayed byt he MicrosoftExcel software (fig.7):

Table 11.Decision matrix for the proposed multicriterial problem

\begin{tabular}{|c|c|c|c|c|c|c|}
\hline $\begin{array}{l}\text { Criterions of } \\
\text { decision }\end{array}$ & $\mathrm{C}_{1}$ & $\mathrm{C}_{2}$ & $\mathrm{C}_{3}$ & $\mathrm{C}_{4}$ & $\mathrm{C}_{5}$ & $\mathrm{C}_{6}$ \\
\hline $\begin{array}{l}\text { Cosfficients of } \\
\text { importance }\end{array}$ & 0,1 & 0,3 & 0,2 & 0,2 & 0,2 & 0,1 \\
\hline $\mathbf{V}_{1}$ & 0,5 & 1,5 & 0,8 & 0,4 & 0,8 & 0,3 \\
\hline $\mathbf{V}_{2}$ & 0,5 & 0,3 & 0,6 & 0,2 & 0,4 & 0,5 \\
\hline $\mathbf{V}_{3}$ & 0,3 & 1,5 & 0,8 & 0,6 & 0,6 & 0,4 \\
\hline $\mathbf{V}_{4}$ & 0,1 & 1,5 & 0,2 & 1,0 & 0,4 & 0,1 \\
\hline
\end{tabular}

Based on decsion matrices in Tables 10 and 11, several decision methods and criteria may be applied, scuh as the ,mathematical hope"method from utility theory, which we have also employed in the present paper (see also section 2).

In this respect, let us proceed to change all consequences in utilities, in keeping with formula (2) resulting in the data in table 12 by means of the MicrosoftExcel software:

Table 12. Utility matrices for the proposed multicriterial problem

\begin{tabular}{|c|l|l|l|l|l|l|}
\hline $\begin{array}{l}\text { Criterions of } \\
\text { decision }\end{array}$ & $\mathrm{C}_{1}$ & $\mathrm{C}_{2}$ & $\mathrm{C}_{3}$ & $\mathrm{C}_{4}$ & $\mathrm{C}_{5}$ & $\mathrm{C}_{6}$ \\
\hline $\begin{array}{l}\text { Cosfficisnts of } \\
\text { importance }\end{array}$ & 0,1 & 0,3 & 0,2 & 0,2 & 0,2 & 0,1 \\
\hline $\mathbf{V}_{1}$ & 1,0 & 1,0 & 1,0 & 0,25 & 0,67 & 0,0 \\
\hline $\mathbf{V}_{2}$ & 1,0 & 0,0 & 0,67 & 0,0 & 0,0 & 0,29 \\
\hline $\mathbf{V}_{3}$ & 0,5 & 1,0 & 1,0 & 0,5 & 0,33 & 0,14 \\
\hline $\mathbf{V}_{4}$ & 0,5 & 1,0 & 0,0 & 1,0 & 1,0 & 1,0 \\
\hline
\end{tabular}

We have calculated the synthetic utility for each type of drinkig water, according to the formula (3), and further to the synthetic utilities we have designed a new matrix by means of MicrosoftExcel:

Table 13. Levels associated to the types of water in the proposed multicriterial problem

\begin{tabular}{|l|l|}
\hline $\mathbf{V}_{\mathbf{1}}$ & 0,78 \\
\hline $\mathbf{V}_{2}$ & 1,67 \\
\hline $\mathbf{V}_{3}$ & 1,21 \\
\hline $\mathbf{V}_{4}$ & 1,98 \\
\hline
\end{tabular}

To conclude, the final column shows that the qualitative hierarchy of drinking water is:

1) $\quad \mathbf{V}_{4}$ chlorinated water provided to the consumer by Avrig Water Treatment Station = optimum version;

2) $\quad V_{2}$ chlorinated water provided to the consumer by Lunca Ştezii Water Treatment Station;

3) $V_{3}$ chlorinated water provided to the consumer by Dumbrava Water Treatment Station;

4) $V_{1}$ chlorinated water provided to the consumer by Cisnădie Water Treatment Station; 
We have applied the utility theory, similarly to section 2 , and performed the model simulation by means of MicrosoftExcel, in order to obtain the results given in figure 7 :

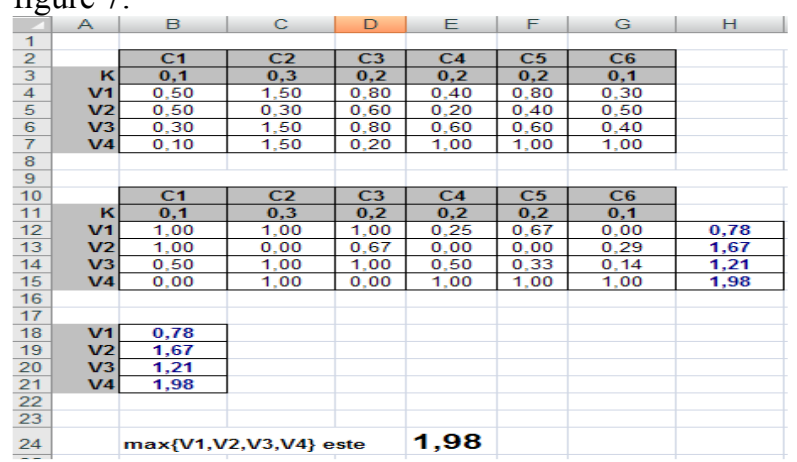

Figure 7. Simulation in MicrosoftExcel

The concluding remark shows that the $\mathrm{V}_{4}$ alternative is the optimum one, hence the $\mathrm{V}_{4}$ type of drinking water has the highest quality, given the circumstances that the selection of $a_{i j}$ initial elements has been influenced by the assessment and expertise of managers and organizers.
1) $V_{4}$
2) $\mathrm{V}_{2}$
3) $\mathrm{V}_{3}$
4) V1

Should the value levels assigned to the $V_{i} i=1, . ., 5$ alternatives on a Likert scale form 1 to 5 , in relation to the $\mathrm{C}_{\mathrm{j}}$ criterion, i.e. $\mathrm{Ni}\left(\mathrm{C}_{\mathrm{j}}\right)$, the $k_{j}$ relevance coefficients and the occurrence probabilities of the $\mathrm{p}\left(\mathrm{S}_{\mathrm{h}}\right)$ situation, then the optimum alternative selected by means of the multicriterial decision would be different. Therefore, its identification depends on estimates and the managerial expertise in interpreting the problem data.

\section{REFERENCES}

[1]Cude, C.G., „Oregon Water Quality Index A Tool For Evaluating Water Quality Management Effectiveness", Journal of the American Water Resources Association, 37, 1,2001, pp. 125-137.

[2]Gurzau, A.E., Popovici, E., Pintea, A., Popa, O., Pop, C. \& Dumitrascu, I., „Quality of Surface Water Sources from a Central Transylvanian Area as a Possible Problem for Human Security and PublicHealth", Carpathian Journal of Earth and Environmental Sciences, 5, 2,2010, pp.119-126.

[3]Güler, C., Thyne, G.D., McCray, J.E. \& Turner, A.K., ,Evaluation of graphical and multivariate statistical methods for classification of water chemistry data", Hydrogeology Journal, 10, 2002, pp.455-474.

[4]Oprean, L., Poplăcean, M., Georgescu, N., „Monitorizarea nivelului de poluare microbiologică a surselor de alimentare cu apă ale municipiului Sibiu”, Analele Societății Naționale de Biologie Celulară, Editura Risoprint Cluj-Napoca, IX, 2, 2004, pp.333-338.

[5]Oprean, L., Poplăcean, M., Georgescu, N., „Monitorizarea bacteriologică a apei din sursele de alimentare cu apă ale mun.Sibiu”, Analele Societății Naţionale de Biologie Celulară, Editura Risoprint, Cluj-Napoca, X, 2005, pp.266-274

[6]Resteanu, C., ,, MADM. Teorie şi practică”, ICI Publishing Press, 2006,Bucureşti(in romanian)

[7]Sa'nchez, E., Colmenarejo, M.F., Vicente, J., Rubio, A., Garci'a, M.G., Travieso, L. \& Borja, R., „Use of the water quality index and dissolved oxygen deficit as simple indicators of watersheds pollution", Ecological Indicators, 7, 2007, pp.315-328.

[8]Singha, K.P., Malika, A., Mohana, D.\&Sinhab, S., ,Multivariate statistical techniques for the evaluation of spatial and temporal variations in water quality of Gomti River (India) - a case study",Water Research, 38, 2004, pp.39803992.

\section{Creative Commons Attribution License 4.0 (Attribution 4.0 International, CC BY 4.0)}

This article is published under the terms of the Creative Commons Attribution License 4.0

https://creativecommons.org/licenses/by/4.0/deed.en_US 